\title{
1. Collective concerns: from policy studies to public action
}

Edward by the Grace of God, King of England, Lord of Ireland, and Duke of Guyan, to all to whom these presents shall come, sends greeting: we have seen the charter of the Lord Henry our father, sometime King of England, concerning the Forest in these words.

(...)

Know ye, that we, unto the honour of Almighty God, and for the salvation of our soul and the souls of our ancestors and successors, to the advancement of Holy Church, and amendment of our realm, of our mere and free will have given and granted, to all archbishops, bishops, earls, barons and to all of this our realm, these liberties, following, to be kept in our kingdom of England forever.

(...)

Every freeman may agest his own wood within our forest at his pleasure, and shall take his pawnage. Also we do grant, that every freeman may drive

his swine freely without impediment through our demesne woods, for to agest them in their own woods, or else where they will. And if the swine of any freeman lie one night within our forest, there shall be no occasion taken thereof, whereby he may lose anything of his own.

(...)

(The Charter of the Forest contains part of the 1215 Magna Carta and with minor revision was re-issued in 1225. Transcript from The National

Archives, UK)

\section{INTRODUCTION}

Why would somebody start a book entitled Beyond Public Policy with a quotation from an early Norman English statute? Could it be because the Charter of the Forest is often referred to, along with the Magna Carta, as one of the moments in institutional history when it is possible to get a sense of some kind of discussion about liberties? There are references to the free movement of pigs and, in other parts, to other activities that together suggest that forests, especially the royal forests covering large parts of England, were far more complex in their physical make-up and in their political, economic and social importance than the scaled-down versions of woods that are current today. ${ }^{1}$ However, even though it may 
be comforting to trace the discussion of rights or budgeting (in the case of the Magna Carta) to these earlier events and social processes, they are beyond current comprehension for most scholars, apart from those highly skilled medievalists for whom this is a lifetime's work. Nonetheless, and despite this somewhat impenetrable distance, there clearly was some kind of issue, concern or dilemma to be resolved. How those who took part in the discussions talked about this and what terms they used is unavailable; because there are no meeting notes, recordings or scraps of private memoirs. But they certainly got on with it somehow.

Most current societies are what they are because, over the years, people as families, tribes, villages, nations and other forms of collective life, have found it useful to regard certain happenings as mutually important and have sought ways of talking about and doing something about them. Which people were considered as legitimate to engage in the definition of questions, actions and the form of their presentation never was, and continues never to be, synonymous with the totality of those present. Over the years the social ideas about how these different bits and pieces should be linked together changed, sometimes dramatically, and will continue to do so. ${ }^{2}$ As the years passed, these different ways of thinking and talking about who, what, when and how began to be brought together under what is today called the discussion of government and governing.

The Charter of the Forest was just one of many moments in which, because it was registered, it is possible to get a small glimpse of these social processes in action. There were many other moments before this that have left their traces in buildings, seals, drawings and other icons. There are glimpses in traditional verse, religious and early philosophical texts and, along with the introduction of printing, important analyses of the broader flow of intellectual ideas. ${ }^{3}$ But, until recently, it has been very difficult to get much sense of the more practical side and especially the discussions of the actions themselves. That is, to ask how people talked to one another, framed their concerns, decided who to listen to, where to seek guidance and what to do.

Beyond Public Policy is concerned with part of this ongoing flux of ideas. Starting from the empirical recognition that public policy is currently 'the' articulating concept for talking about government in action, it wonders what happened to the many other forms of discussing and doing public affairs that were present before policy began to move to the centre of the stage, in the 1970s and 1980s. How did actions in the public arena happen in other moments, what did governments do when they didn't have policy and what happened to the terms, expressions and meanings that they used? Did these different action languages bow down and rearrange themselves within the organizing characteristics of this 
new and clearly important concept? Did they become obsolete, or are they still around and what does this say about the dynamics of public affairs? How central in fact is public policy; is it 'the' synonym for the work of government? To answer these and other questions it is necessary to get beyond public policy and, as it were, look at it from the outside. To ask what was around before, what is still around today and what may be currently emerging.

For the social scientist faced with the challenge of learning from history, even from recent history, it is easy to fall into the trap of reading history from the present to the past, or, as historians say, 'reading history backwards' and to assume that all earlier peoples had governments, forms of representation, public agendas, budgets, policies and such like. ${ }^{4}$ It may be helpful to organize material in certain of today's categories as a way of indicating the type of question under study, but the danger comes when this is taken as a description of what was actually happening. Indeed, in many cases and until recently, nobody would have a clue about what is meant by most of the current terms in use for discussing governing or, if they were used, it would be in a very different manner. In addition, as Thompson pointed out in contrasting the complexity of the actions of the English crowd in the eighteenth century with the modern view of uncontrollable riots: 'It is difficult to re-imagine the moral assumptions of another social configuration. It is not easy for us to conceive that there may have been a time, within a smaller and more integrated community, when it appeared "unnatural" that any man should profit from the necessity of others' (1971, p. 131).

Why, it may well be asked, such concern with public policy? After all, isn't it obvious that there are policies? Today, if there was a panel to select the one contemporary expression most present when politicians, journalists, academics and international advisors talk about responsible public affairs and government in action, it is likely that this will be some variant of public policy. It seems so natural to talk about policy documents or policy advisors and there are many thousands of scholars, students, courses, conferences, books, politicians and public sector workers for whom the world of public policies is as real as night and day. Yet, as the different chapters will show, it is only one amongst many ways of talking and doing public affairs and, in its current form, dates from the end of the 1960s in the USA, the 1970s in the UK, the 1980s in France and Spain and the 1990s in Brazil, amongst others.

Humankind is where it is because it never stopped tinkering with its basic rules, concerns and their resulting procedures and collective forms. In order for that to happen, people had to meet in talk and there is no reason to assume that such talk was consensual. Equally, the notion of 
government and the practice of governing brings certain assumptions about who does what for whom, which leads to other assumptions about how this takes place and the different social action languages in which this takes place. Government and public policy are only two of these, budgeting and planning are others, public administration is another, and while government has had a relatively long life as an expression, with public administration somewhat shorter, policy is a relative newcomer. Yet, in this short time, it has come to dominate the way people talk about doing public administration and government as a central component of the democratic order. Policy, then, seems a good idea; good ideas are almost by definition useful and the public sector has long been a source of, and a market for, good ideas. Indeed, as Beyond Public Policy will argue, there is no problem in public policy being just one more contribution to an expanding universe of social ideas that different parts of humanity create for themselves in order to do and describe certain relations and actions. Nor is it a question of being right or wrong. Lots of people use the notion. It seems to create bridges between different parts of society, connecting citizens to politicians, giving meaning to the activities of administrators, enabling political parties to vie for public attention, and it allows academics to comment on what to do about a wide range of issues.

As long as there are themes, topics, issues and questions of public concern, there will also be ideas, arguments, concepts and techniques for actions in relation to these concerns. Public policy is a language for action that is shared by many people. It is a social language: part professional, part political and part everyday. As a concept, it may seem at times abstract, as also are themes like justice, but doing justice is as performative as making public policy. Social languages are comfortable for those who use them and policy, in this sense, is no different; it makes sense of a part of the world. However, there are problems.

First, although it may be seen as central it is only one of a number of similar social languages, equally part professional, part political and part everyday, that can be found in and around government action. Take, for example, budgeting, finance, planning, diplomacy, rights, systems, directives, decisions and laws, as well as the many different versions of public administration or management, amongst others. They are rarely hierarchically or logically related, frequently have their own professional roots and can be found in different departments, ministries and branches of government. Some of them have been in place for a long time before policy, others are more recent or emerging. Some were seen as equally central in their times and others may be vying for centrality. They are also languages which are comfortable to be positioned within, from 
which to make sense of the world. Within each there will be different approaches and even different theories - just as in public policy.

Second, there is the problem with centrality itself. Ideas will arise which help solve certain questions and offer frames for organizing affairs. In doing so they will create their own social languages but, in time, others will appear to offer better possibilities. Currently, in a number of areas it is governance that seems to be moving ahead, even though the rhetorical structure for this proposition has curious similarities to what has been said before. Here for example are the editors of a recent handbook on Governance:

Concepts and approaches come and go in the social sciences. Some of them are more than passing moments and become steadily growing research areas that attract increasing scholarly attention. Some of the new research areas are stabilized and consolidated and gradually take the form of new paradigms that signal a scientific turn and give rise to a significant reorientation of the scholarly activities of researchers and the ideas and actions of practitioners. The research on governance has recently evolved into such a paradigm. Although the notion of governance can be traced far back into history, the interest in governance surged in the 1990s and has grown ever since. Today, governance is one of the most frequently used social science concepts in the world, as any internet search will readily confirm. A vast array of researchers, research centers, journals and conferences are devoted to the study of governance, and many new theories of governance have been promulgated over the last two decades. (Ansell and Torfing, 2016, p. 1)

Centrality might make normative sense as a device for organizing books and courses, but if government action, governing in the broader sense, is performed by a heterogeneity of different social languages, is there any practical sense in centrality; that is, of a specific social language that somehow holds everything together? Some of the languages may interact with each other on similar terms, but others may have their distinctive hierarchical views on which is more dominant. Others, again, may inhabit very different parts of the public landscape and go their own way. For example, the UK Secretary of State for the Ministry of Housing, Communities and Local Government, by Command of Her Majesty, presented the National Planning Policy Framework to Parliament in July 2018 (Cm 9680). The document uses planning, policies, framework, law, development plan, decision, planning policies, international obligations, statutory requirements, ministerial statements, planning system, sustainable development, overarching objectives, presumptions, plan-making and decision-taking - all in the space of the opening three pages. All those who are active in the field of housing, communities and local government presumably understand what is being said and know how to 
position themselves within the text. But does it make sense to talk about an overriding and central 'something' that holds all this together?

If these first two problems raise serious doubts about the idea of public policy, or anything, as the main articulator, or even synonym, of government in action, a third is far more crucial. Is collective life merely a question of government and the governed - even if both are 'the people'? How do the parishes, the friends of the library, the local historical society, the neighbourhood babysitting circles and community associations fit in? What about the many charities, philanthropic bodies and micro-collective soup kitchens, street parties and animal rescue centres? What about the pressure groups and social movements, interfaith networks, community activists and street protests which also have their action languages, and which are just as social in their own ways? They are also heterogeneous, also comfortable to be within, and also are ways of making sense of parts of the world. Is governing just about representation or is it also about those who independently voice the concerns that they feel are present: the different publics and their problems (Dewey, 1927) or, in today's terms, their issues and rights?

The result, as the book will seek to show, is that it is necessary to go beyond public policy and recognize the many other social languages for public action present, not as auxiliaries but as equally active players in and around public affairs. Present in the not necessarily harmonious relationships between governments, representatives and the people they serve; and present in those areas of action where, for varying reasons, the public or public(s) prefer to get on and do it themselves. Understanding these differences and learning how to create and negotiate possibilities, rather than seeking to impose new centralities, is the challenge to be faced.

As a final point, going beyond public policy means looking outside public policy at what is also happening in other social languages. Public policy as currently understood appeared gradually in different western democracies in the late 1960s, 1970s and 1980s. It follows therefore rather than is a precursor of - many of the key developments of the modern welfare states. If it is not key in their formation, what then is its role and relationship? Why did it become so popular? The answer to this is beyond the scope of the book and would require a different form of study - but there are at least suggestions that can be made.

\section{SOCIAL LANGUAGES AND PUBLIC ACTION}

Paying attention to the performative aspect of language has been a fairly constant theme in the social sciences since the late 1950 s, stimulated to a 
large extent by the debate in philosophy on language and action. In different ways, some more radical than others, the result was a swing from the idea of an independently existing out-there reality to one that was performed through language. This swing, often described as the linguistic turn because of the 1967 volume edited by Rorty, also resulted in a number of different proposals and ideas, such as social construction, post-empiricism and postmodernism, as well as expressions such as enactment and structuration, that were concerned with the more specific performative aspects. Overall, it is much less a paradigm, school of thought or a specific theory; rather the move is to multiple ways of looking at the way words produce what takes place rather than just describe it. Furthermore, it assumes, in different ways, that people are conscious performers. They are very aware that the answer 'I do' to a question about who wants chocolate sauce on their ice cream is very different to the same 'I do' in a marriage ceremony.

Austin introduced the idea of performatives in his 1962 text on how to do things with words and later Butler was to use the term in an important text on gender and feminist theory (1988). Amongst the different consequences of these ideas was a growing attention to discourse analysis and discursive practices and, more specifically for Beyond Public Policy, to the way that social meanings circulate in the day to day within scientific and professional communities - what have been called interpretive repertoires. ${ }^{5}$ In a similar vein, Bakhtin saw social language as 'a discourse peculiar to a specific stratum of society (professional, age group, etc.) within a given social system at a given time' (Bakhtin, 1981, p. 430). In his later essay on speech genres, Bakhtin provides a further definition when discussing the inseparable link between style and genre: 'A particular function (scientific, technical, commentarial, business, every day) and the particular conditions of speech communication specific for each sphere give rise to particular genres, that is certain relatively stable thematic, compositional and stylistic types of utterances.' (Bakhtin, 1986, p. 64). Hence, when people are described as public policy advisors, or there is talk about policy making, policy processes, policy documents or policy presentations, these terms will be found as part of repertoires that both make sense of policy and, in doing so, are policy themselves. Similarly, planning, budgeting and the many other public action practices are also performative social languages, or, to use an earlier expression of Fleck, thought collectives (1935). They are ways of enacting public affairs.

To argue that there was a very effective public life before policy, that these different social languages are still very present and that they will continue, along with policy, to play their part if or when the next centre 
stage social language comes along, is not a straightforward task. To begin with, handbook after handbook seems to be able to extend the field of policy studies into new epistemological and critical dimensions. ${ }^{6}$ The impression is given that there is nothing that policy cannot do and no end to its elasticity. Also, the frequent mention of new paradigms coupled with the characteristics of many disciplinary social epistemologies, ${ }^{7}$ suggests that there is little need to look at what went before; knowledge is driven by the assumption that what is recent is what is important.

However, the action languages of the English crowd of the eighteenth century didn't disappear with the arrival of different forms of economic relationship, labour unions and new patterns of representation and pressure. Observers and chroniclers may have switched their attentions, but social languages remain social. A few may disappear without trace, others blend into new circumstances, new ones will appear, but some will keep on making sense of the world. They can be found in the corridors of public sector agencies, in the tumult of protest and campaigns, in speeches and documents or in the solidarity of community-based service provision. Being performative, they may cooperate or compete with one another for place and space, or at times just go their own way, living parallel lives. It is not a question of preferring one over the other, but of paying more attention to these different attempts to order collective life, including, most importantly, the assumption that collective lives can be reduced to what governments do. What is under discussion in Beyond Public Policy is not a change from one central articulating concept to another, but the very idea of the central concept itself.

Paying more attention to the performative aspects of social languages means recognizing that they are socio-technical. They introduce ways of doing things, give new meanings to old objects, create new objects which in turn create new meanings and institutionalities, as well as suggesting different ways of seeing things; they can be soft technologies ${ }^{8}$ but produce a lot of hard bits and pieces. Discussion on traffic control may acquire the notion of calming or taming; from somewhere will come the idea of putting raised bumps on the roads in key areas; speed bumps become known as sleeping policemen in certain parts of the world, giving a different social twist on a very solid object. But these new microinstitutions are by no means inevitable and are also open to challenge. Ahmed Kathadra devoted his life from an early age to the South African freedom struggle and was sentenced to life imprisonment along with Nelson Mandela at the 1963 Rivonia Trial. In his memoirs, he reflected on getting used to life after being released in 1989: 
As for language use, efficiency aids and jargon, I recall how activists in the 1940s and 1950s managed to organize the Passive Resistance Campaign and the Defiance Campaign, the boycotts of potatoes, tobacco and buses, and the Congress of the People without the benefit of consultants, events organisers, brainstorming sessions, strategic workshops, think tanks, key note addresses, organograms and so on. I still have not fully adjusted to these, and I suspect my comrades are exasperated whenever I question the necessity for these so-called aids. (Kathadra, 2004, p. 348)

Passive resistance campaigns, boycotts and congresses are just as much a part of public affairs and collective life as are votes, plans, budgets and policies; and they too have their social languages and repertoires, key meanings that circulate and make sense of activities. It is difficult, when thinking about collective life, in the west not to be influenced by a common theme in Judaism, Islam and Christianity: concern with the unknown other. There are similar elements in the east, the north and the south; indeed, if there weren't it would probably have been impossible to arrive at the idea of universal human rights and its underpinning notions of dignity and humanity in the 1940s. Faith-based organizations, at least in western public sector literature, are rarely talked about when the subject of social policy and non-governmental organizations comes up. Yet, as service providers and first responders in times of crisis they are a ubiquitous presence in thousands of communities. Parish halls, synagogues and mosques are the meeting places of associations, playgroups, debating societies all throughout the west, and their members and leaders are often at the forefront of a number of key public issues, especially those linked to inequality.

Indeed, the many different ways of ordering collective life go on even further, beyond the spheres of government and religion to include other notions of community such as neighbourhood associations, assembly halls, meeting rooms, clubs and societies which, with the technologies of printing and writing, enabled people to produce minutes, pass out pamphlets and register events. Civil society, as it is called today and somewhat different to Ferguson's earlier conception of the dedication to civil concerns (1767), should never be taken as a synonym of collective cooperation with government. Long before the current arrangements of relatively stable political parties, general franchise, transparency and accountability, the different social languages of protest played and continue to play their part. All of this, and more, is collective life. Here, Rosanvallon's approach to the political and its history provides another important starting point:

As I understand it, 'the political' is at once a field and a project. As a field it designates the site where the multiple threads of the lives of men and women 
come together, what allows all of their activities and discourses to be understood in an overall framework. It exists in virtue of the fact that there exists a 'society' acknowledged by its members as a whole that affords meaningfulness to its constituent parts. As a project, the political means the process whereby a human collectivity, which is never to be understood as a simple 'population', progressively takes on the face of an actual community. It is, rather, constituted by an always contentious process whereby the explicit or implicit rules of what they can share and accomplish in common - rules which give a form to the life of the polity - are elaborated. (Rosanvallon, 2006, p. 34)

This is where the second part of the book's title requires an introduction. The notion of public action has been around in a civic vein for a number of years as, for example in Hirschman's (1982) discussion of public and private interests: 'Public action, action in the public interest, striving for the public happiness - these all refer to action in the political realm, to involvement of the citizen in civic or community affairs' (p.6). At around the same time, it began to assume a more precise definition that has carried it through much of the last 30 years, especially in French pragmatic sociology. Sometimes, in translation, there is a tendency to switch action publique into policy, but there is a subtle and at the same time quite radical distinction between the two that is followed by a majority of authors. ${ }^{9}$ In an earlier key text on the discussion of development and hunger, Dreze and Sen (1989) used public action to mean: "not merely the activities of the state, but also social actions taken by members of the public - both "collaborative" (through civic cooperation) and "adversarial" (through social criticism and political opposition)' (p. vii). Thoenig (1997) will make the same distinction in pointing out that the state does not have the monopoly over the public nor have the public given up their control over what they see as public or of their own autonomy for action. The same line can be found in the introduction to Laborier and Trom's (2003) collection of readings on historical and sociological aspects of public action:

Public action is understood, in the broad sense, to cover the activities of the public powers and more widely all activity articulated in a public space and in reference to a common good. This extensive definition brings together in the same area of activity, those actions directly as a result of public authority and those that come from the ordinary activities of citizens as they show their concerns about collective life (p. 11). ${ }^{10}$

It is not uncommon to find reference to 'action by the public' in discussions of public affairs. However, often this is reduced to either pressuring for change, for example through civil society organizations, or 
as a reference to the fact that most public services depend on public collaboration to be effective. Beyond Public Policy goes beyond this 'add-on' approach to public affairs and takes the ordinary actions of citizens, for and from themselves, as equally important as those of government and as creating distinctive arenas of public action. As will be seen as the book progresses, at many times in the past and the present, actions take place not because 'government isn't doing something, therefore ...' but because of a collective and independent sense that 'we must do something about ...'.

Putting the two parts of the title together, the field of public action suggests an ever-changing and complex arena which is formed by these very different social or action languages. There is no presumption that there is a logical relationship and, despite professional or disciplinary pressures, much less a hierarchical ordering. Policy is in there somewhere, but that is all. For all practical purposes, it is only one in a line of new kids on the block when seen from some parts of the governing side of affairs and totally ignored in many other areas of public action. ${ }^{11}$

\section{GETTING THINGS DONE WITH OTHER WORDS - THE EXAMPLE OF DIRECTIVES}

At this point it is useful to bring in an example of just one of these many other terms. Article 288 of the Treaty of Lisbon (2007) on the functioning of the European Union (EU) establishes five ways in which the EU can exercise its competence. These are: regulations, directives, decisions, recommendations and opinions. Directives are 'binding, as to the result to be achieved, upon each Member State to which it is addressed, but shall leave to the national authorities the choice of form and methods'.

In the aftermath of the Second World War the same term, directives, with the same operational meaning, was to play a key role in the recuperation of daily life in Germany. There, the Allied military leaders faced not only the questions of demobilization and security, but the problems and traumas of different peoples in shock, without food, work and often without shelter. Germany had been divided into four occupied zones (one for each of the Allies) and, while there was also an overall Allied Control Council, each zone was more or less independent in the early stage. A recent study by Knowles (2014) has traced part of the story of reconstruction in the British zone. The situation being faced was catastrophic: 
In May 1945 Germany was in chaos. Observers reported that the destruction in some of the larger cities had to be seen to be believed with, for example, $66 \%$ of the houses in Cologne destroyed, and in Düsseldorf 93\% uninhabitable. The economy was at a standstill and no central government remained to implement instructions issued by the Allies. Millions of people were homeless, or attempting to return to homes that no longer existed (...) Field-Marshall Montgomery, appointed Commander-in-Chief and Military Governor of the British zone of occupation on 22 May 1945, later recalled the immediate problems they faced: what to do with 1.5 million German POWs, a further million wounded German soldiers, similar numbers of civilian German refugees and Displaced Persons of many different nationalities, no working transport or communication services, industry and agriculture at a standstill, a scarcity of food and the risk of starvation and epidemics of disease. He added that: 'I was a soldier and had not been trained to handle anything of this nature ...'. (Knowles, 2014, p. 2)

The language they used to talk about what was necessary was the same language of directives that can be found in the Treaty of Lisbon in 2007. Directives say what is to be achieved but leave open the choice of how. Directives were, and continue to be, a long-standing part of military language, something which all military leaders at that time had been actively using for the previous seven years. In the words of Montgomery's Deputy, General Brian Robertson, written in January 1946:

The directives were not many and much was left to the initiative of individuals ... the (military) detachments entered into a land of desolation and bewilderment. Government above the level of the parish council had ceased. Everything was in disorder; people were stunned and helpless ... 'First things first' was the motto when the Military Government first raised its sign in Germany. (Cited in Knowles, 2014, p. 3)

The directives focused on rebuilding economic and political life. In Knowles' description:

As early as July 1945, less than three months after the end of the war, he (Montgomery) issued a new draft directive to British army commanders and Control Commission heads of division, finalised on 10 September 1945. Unlike earlier wartime directives, the new directive identified steps to be taken to reconstruct German economic and political life, address shortages of food, fuel and housing, improve transport facilities, re-open schools, permit freedom of assembly, licence political parties and prepare for future elections. Con O'Neill a senior Foreign Office official and leading authority on Germany, minuted that the directive 'gives me, in general, the impression that British Military Govt. has now embarked on a policy of Full Speed Ahead for German rehabilitation'. (Knowles, 2014, p. 3) 
The results were by and large successful in many areas, much more so than the desperate consequences of the First World War (one of which will play a part in the next chapter), and, despite problems with housing and food supply, they were able to provide an important period of stability.

Directives are a social action language like many others. They identify goals and responsibilities, but like in the Treaty of Lisbon, do not go into the methods. They were also part of an action language that was familiar to those involved, even though the themes and issues were totally new. Different to current notions of policy, there is no mention of implementation; it is assumed that the directives are viable and that those involved are able to find a way through. As Knowles reports, the results were considerably more effective than could have been imagined. Policy was 'full speed ahead' an expression of a stance, posture or position, as will be discussed in the following section and whose variants, such as 'let's get on with it', will also be found in Chapter 4.

While article 288 of the EU does not use policy, the word can certainly be found when the concern is with different issue areas, such as the common agricultural policy (CAP):

The common agricultural policy (CAP) is aimed at helping European farmers meet the need to feed more than 500 million Europeans. Its main objectives are to provide a stable, sustainably produced supply of safe food at affordable prices for consumers, while also ensuring a decent standard of living for 22 million farmers and agricultural workers. (EU Common Agricultural Policy, Agriculture and Rural Development, overview, June 2016)

The CAP has hundreds of different actions in different areas, and half an hour wandering around the CAP section of the EU website will be enough to identify all sorts of different ways of talking about the different ongoing actions. As the example suggests and the book proposes, no one expression is correct nor is there a specific definition for each term that enables them to be placed in order on a conceptual bookshelf. Rather, it is to take all of them seriously and look at the realities they enact and perform.

\section{POLICY BEFORE THE POLICY SCIENCES}

If public policy and public policies are newcomers to talking about action in public affairs - less so in some countries and action arenas, more so in others - the same is not the case with the word policy itself. Some of its different threads of meaning are continuous and others discontinuous, 
and as with the emergence of ideas and notions in other areas and fields, it is certainly not a question of asking where, when and much less why. It appears, as police, in relation to order or local government in various versions in different languages, and some kind of generic notion of policy - as a course of action or position in relation to action that is adopted as advantageous or expedient - can already be found in the English language when the new technology for printing books helped stimulate the standardization of the language in the sixteenth and seventeenth centuries. ${ }^{12}$ Here are two much-used examples: honestie the best policie (1599) or thys was the crafty polycye of the clergye (1544). ${ }^{13}$

Another thread of meaning can be found in the materialism that arrives along with notions of risk, insurance and, later, Lloyd's of London: policy as a written promise. Who does not have an insurance policy kept safely somewhere from the days before digital transactions. Adding in other bits and pieces related to the polis, police, polity, even government itself, it is not too difficult to imagine the gradual social, organizational and inter-organizational sensemaking (Weick, 1995) that will lead to a 'posture towards action', or of the importance of some kind of declaration about how a person, community or society can be expected to act in certain circumstances, including in the public arena. Without falling into the trap of suggesting a magical starting point, certainly one of the early areas of government in which this seems to happen is that of foreign affairs - see, for example, the foreign affairs speeches collected by Jones (1914), a member of the UK parliament, in his book on British oratory.

Here is the Earl of Chatham, otherwise William Pitt the Elder, addressing the House of Lords in London on 22 January 1770 on the topic of the defence of weaker states:

My Lords, I cannot agree with the noble duke, that nothing less than an immediate attack upon the honour or interest of this nation can authorize us to interpose in defence of weaker states, and in stopping the enterprises of an ambitious neighbour. Whenever that narrow, selfish policy has prevailed in our councils, we have constantly experienced the fatal effects of it. By suffering our natural enemies to oppress the Powers less able than we are to make a resistance, we have permitted them to increase their strength; we have lost the more favourable opportunities of opposing them with success; and found ourselves at last obliged to run every hazard, in making that cause our own, in which we were not wise enough to take part while the expense and danger might have been supported by others. (Jones, 1914/2004, p. 7)

Pitt used the term policy very much as posture or position, but with a focus: the action of governments to other governments. As there is no information on how Jones made the selection, it can only be assumed that 
they were at least a partial cross-section of parliamentary themes and addresses. In his collection, policy appears in the text of many speeches on foreign affairs (for example George Canning, Foreign Secretary, addressing the House of Commons on negotiations relative to Spain, 30 April 1823), but it would only be much later that it appears in the titles of speeches themselves. (For example, the speech of John Bright on 'Principles of Foreign Policy' delivered in Birmingham, 1858, or of Gladstone on the 'Right Principles of Foreign Policy' in West Calder, Midlothian in 1879).

This idea of policy as posture or position, with its fairly long history of usage, can be considered almost as vernacular, part of the everyday horizon of rhetorical possibilities of at least that part of the population that shared a more general dialect or were able to read similar texts. It can be found in other fields than that of foreign affairs but it is certainly in the sphere of relations between countries that it was most present in public life. Indeed, it could be argued that, as the western world very slowly settled down to the idea of nations, the idea of knowing how countries stood on certain issues became an important tool for governments and leaders. To take a stance on issues or problems requires recognizing some set of affairs or questions as problematic. It also implies that there will be topics on which, for a variety of reasons, there might be no positions to be held; a theme that will appear in later chapters.

In 1867, journalist Walter Bagehot published a collection of essays with the title The English Constitution. The following citation is from the introduction:

No one can approach to an understanding of the English Institutions, or of others which being the growth of many centuries exercise a wide sway over mixed populations, unless he divide them into two classes. In such constitutions there are two parts (not indeed separable with microscopic accuracy, for the genius of great affairs abhors nicety of division): first, those which excite and preserve the reverence of the population, - the dignified parts, if I may so call them; and next, the efficient parts, - those by which, it in fact, works and rules. There are two great objects which every constitution must attain to be successful, which every old and celebrated one must have wonderfully achieved: - every constitution must first gain authority, and then use authority; it must first win the loyalty and confidence of mankind, and then employ that homage in the work of government. (Bagehot, 1867, p. 4-5)

In describing a host of different traditional customs and practices and publishing them together under a single title, Bagehot, as Burke and Pallares-Burke comment (2016), could be said to have invented the 
British constitution. It was certainly something that he and his fellow Victorians were fond of discussing. The mix of acts of parliament, court judgements, conventions and charters was never coded and keeps getting added to, but this does not stop the British from feeling a sense of constitutionality nor of his book being studied, even today, by ministers and monarchs.

Bagehot's text is an early account of how the different institutions of politics happen in the day to day. His delicate demolition of the belief in the legal separation of institutions, through his analysis of monarchical powers and the executive power of Cabinet, is an early warning not to assume normative definitions as actual descriptions and has much to contribute to the current discussion on 'policy work'. Perhaps the best indication of his influence is that, even today, the journal which he helped transform into the world's leading economic weekly (The Economist) continues to publish a regular commentary on British life and politics under his name. The few times that Bagehot used the word policy were, as could have been expected given previous comments, as: foreign, international or national policy, or as the policy of parliament, government, department (the English word for ministry), monarch or presidents and assemblies in the case of comparisons with other countries; in all cases, policy as posture, position, or as an approach to be taken.

In the USA, influential texts were beginning to be produced on a related question, that of the separation of politics from administration. Woodrow Wilson will talk about the legislative and policy making functions of government but, as he puts it, this does not mean that the administrator is a passive instrument: 'the distinction is between general plans and special means' (1887, p. 212). Shortly after in Politics and Administration, Goodnow (1900/2012) will talk about the two functions of government: politics and administration. He makes this distinction through the idea of operations necessary to the expression of the will of the state or in operations necessary to the execution of that will. 'Politics has to do with policies or expressions of the state will. Administration has to do with the execution of these policies' (p.18). Here, even though the language appears familiar, general plans, special means and expressions of state will are still much more linked to the notion of major areas of posture or approach than to our present-day expressions.

Moving from individual examples to a more archival approach, an important source for reference is the network of official deposit libraries where publishers are required to deposit copies of their publications (a practice that began in France in 1537). In the case of the UK deposit libraries, concern is specifically with British publications, but there are also other English language exchanges. Despite restrictions, and 
assuming that giving titles to books is a social process that happens in conversations, the results can be taken as at least indicative.

The Cambridge University library archives provide support for the view that this early usage of policy as "position or stance on some important concern' was the lead contender for meaning up until the period shortly before the Second World War. In 1826 Joseph Priestley published his Lectures on History and General Policy: To Which is Prefixed an Essay on a Course of Liberal Education for Civil and Active Life and a year later William Phelan published in Dublin a History of the Policy of the Church of Rome in Ireland. Later, in 1905, J.L. Le Breton Hammond wrote Towards a Social Policy: Or Suggestions for Constructive Reform about the early reform movements, and there were histories of British Colonial Policy in 1905 (H.E. Egerton), the Cambridge History of British Foreign Policy in 1922 (A.W. Ward and G.P. Gooch) and of French Colonial Policy (S.H. Roberts) in 1929. Economic policy makes an appearance in 1923 with J.S. Reyes' text on the Legislative History of America's Economic Policy towards the Philippines in 1923 and education in 1931 with Nicholas Hans' History of Russian Educational Policy.

A very similar pattern emerges from the British Library catalogue where there are 4,110 different printed items with policy in or near the title from 1600-1950. Of these, most of the earlier uses are religious and it is only in the nineteenth century that foreign affairs (diplomacy, war and the colonies) start to take over. There are as many items in the 35 years from 1901 as there were in the whole century before (approximately 1,200) and a similar number in the 15 years from 1936. This increase in usage has to be offset in part by the growth of the book and printing industry as a whole, but the range of titles points to the changes taking place. In the first part of the twentieth century, foreign policy has been joined by commercial policy, later economic policy and the policy of specific political parties (for example, liberal policy). Between 19361950 this has been added to again with transportation policy, workers' nutrition and social policy, educational policy in India, but still variants of foreign affairs are very much around. As to public policy, there are only 67 items in the period 1936-1950, mostly from the USA. These are mainly items on economics, a few on secondary education and a collection of classroom materials for discussing current issues of public policy in schools and colleges by the American Political Science Association (Beard and Smith, 1936).

Elsewhere, as with Roosevelt's Social Security Bill of 1935 and even the wartime meetings chaired by Beveridge in 1942 mentioned in Chapter 4 , there is very little if any mention of policy in the way that it 
is understood today - especially when it acquired the extension 'public policy'. Even in the few places that policy appears in Lasswell's classical text Politics: Who Gets What, When, How (1936), it remains in the vernacular. It is not in the index nor in the contents and, when it appears, it is either as national policy or public relations policy and certainly has no similarity to his later arguments. Those who seek to place the definition and paternity of public policy in this book are mistaken.

To finish, here is policy very much as it has appeared in these different texts and citations, reflected in Webster's second edition of the New International Dictionary of the English Language, published in Springfield, MA, in 1934:

1. Civil or ecclesiastical polity; government; the science of government; also a government or state. Now Rare.

2. Prudence or wisdom in the management of public and private affairs; wisdom; sagacity; shrewdness; wit; as, the policy of such a course is doubtful.

3. A wise scheme or device; a contrivance, esp. a cunning contrivance; a stratagem; trick. Now Rare.

4. Management, administration, or procedure based primarily on temporal or material interest, rather than on higher principles; hence more or less disparagingly, worldly wisdom; as, he allowed policy to outweigh honor.

5. A settled or definite course or method adopted and followed by a government, institution, body or individual. Honesty is the best policy. Old Saying.

\section{WHY ARE POLICY SCIENCES DIFFERENT?}

If there is to be one key distinction introduced in The Policy Sciences (Lerner and Lasswell, 1951) it is not in the application of sciences to aid government action; although concern with the contributions of social research, its methods and the role of social scientists in relation to research policy was part of the book. Nor is it in Charles Easton Rothwell's preface to the book on behalf of the Hoover Institute, which provides a very workable and matter-of-fact definition of policy as it was at the time; no longer the policy of foreign affairs but not yet the fully-fledged policy of the 1970s. Rather, it lies in the first of Lasswell's two-part policy orientation: 'A policy orientation has been developed that cuts across the existing specializations. The orientation is twofold. In part, it is directed to the policy process, and in part toward the intelligent needs of policy' (1951, p. 3). He went on to describe: 'In the realm of policy, more attention has been given to planning, and to improving the information on which staff and operational decisions are based. We have 
become more aware of the policy process as a suitable study in its own right ...' (p.3).

Technical and scientific knowledge, albeit in a less organized way, had already been at the service of governments in the previous century (as, for example, in the case of Pasteur) and academic counsel even longer (deLeon, 1989); Policy Sciences would certainly make this relationship clearer. However, the big change lay in the proposal to study the policy process itself, for in doing so it helped to turn policy from a vernacular expression, freely used and readily understood, into a self-conscious discipline. The proposal to study a process presumes, within the broad neo-empiricist framework of the time, that this process exists, independently of the observer. Lasswell was very clear about the novelty of the proposal: "The expression "policy sciences" is not in general use in the United States, although it is occurring more frequently now than before. Perhaps it should be pointed out that the term is not to be taken as a synonym for any expression now in current use among scholars' (Lasswell, 1951, p. 4). Given that the 1951 book and Lasswell's chapter is the most commonly cited starting point of policy studies, it is worth repeating some key parts to be clear about where Lasswell was both going to and coming from.

The word 'policy' is commonly used to designate the most important choices made in organized or in private life. We speak of 'government policy', 'business policy' or 'my own policy' regarding investments and other matters. Hence policy 'is free of many of the undesirable connotations clustered about the word political, which is often believed to imply 'partisanship' or 'corruption' (...) The movement is not only towards a policy orientation, with a resulting growth in the policy sciences, but more specifically toward the policy sciences of democracy. (p.5)

The policy-science approach not only puts the emphasis upon basic problems and complex models, but also calls forth a very considerable clarification of the value goals involved in policy. After all, in what sense is a problem 'basic'? (p.9)

We can think of the policy sciences as the disciplines concerned with explaining the policy-making and policy-executing process, and with locating data and providing interpretations which are relevant to the policy problems of a given period. The policy approach does not imply that energy is to be dissipated on a miscellany of merely topical issues, but rather that fundamental and often neglected problems which arise in the adjustment of man in society are to be dealt with. (p.14)

Easton Rothwell's description in the preface follows similar lines. He had had significant administrative experience during the war and after, where 
he had been the Executive Secretary to the preliminary United Nations Conference on International Organization in San Francisco and then Secretary General of the USA delegation to the United Nations itself.

Planning suggests a systematic attempt to shape the future. When such planning becomes a prelude to action, it is policy-making. For policy, broadly speaking, is a body of principle to guide action. The application of policy is a calculated choice - a decision to pursue specific goals by doing specified things. The formulation and execution of policy usually consists of four steps: 1) a clarification of goals, 2) an exhaustive evaluation of the situation to be met, 3) the selection of a course of action by weighing the probable consequences of various alternatives, and 4) the determination of optimum means for carrying out the action decided upon. Since the situation to be met is normally not static but involves a complex of moving forces, policy and action are, in effect, a design to shape the future by exerting influence upon trends that flow from the past into the present. (Rothwell, 1951, p.xi)

Lasswell's later 1971 text has many of the themes of the earlier text and, while it is usual to find citations of the phrase 'knowledge of and in', there is less attention paid to the wider text within which this is a part and, for that reason, is reproduced below.

As a working definition, we say that the policy sciences are concerned with knowledge of and in the decision process of the public and civic order (...) The emphasis on decision process underlines the difference between policy sciences and other forms of intellectual activity. By focusing on the making and execution of policy, one identifies a relatively unique frame of reference, and utilizes many traditional contributions to political science, jurisprudence and related disciplines. However, these public order decisions do not exhaust the field of policy. In complex societies, the agencies of official decision do not account for many of the most important choices that affect men's lives. In the interest of realism, therefore, it is essential to give full deference to the study of semiofficial and nonofficial processes. The dividing line between public and civic is more a zone than a line, and in totalitarian states the civic order is almost entirely swallowed up by the public order. The separation is most visible in bodies politic where the activities assigned to the formal agencies of government are relatively few and where the collective activities of businesses, churches and other active participants in society are independent of detailed direction from government. (1971, p. 1)

Both Lasswell and Rothwell were concerned with major questions of shaping the future and about the most important choices; what today might be called the big issues to be faced. Whether Lasswell (19021978), who finished his $\mathrm{PhD}$ at the University of Chicago in 1926, would have been happy about the way that future generations would fill in the dots that these comments laid out is beyond conjecture; he had many 
themes to work on and made so many contributions in so many areas, including being considered the founding father of political psychology. Important here is to show that, at least at this time, in the 1950s and 1960 s, there is a transition in progress. The older notion of policy as posture or stance on major issues, still remained, but is now acquiring the idea that knowledge has much to contribute to solving these greater concerns: both in the processes that help decisions along the way and in the understanding of the issues themselves.

Over the next 40 years, policy and public policy would continue to grow and spread from place to place, country to country and from theory to theory. It would acquire both a centrality and a certain mystical air of importance, as this citation from the introduction to a widely used book of readings published in 1995 shows.

In recent years there has been a substantial transformation in the way public policy is studied. The student of policy is faced not only with a diversity of theoretical approaches but also, at times, with rival vocabularies and specialist terminologies. Nowhere is this better illustrated than in the definitions of public policy. Such discussions frequently use a specialized language, indeed often jargon, which often confuses and muddles an understanding of public policy. The one thing, however, that all authors on public policy do agree on is that public policy deeply affects the daily lives of every individual in society. (Theodoulou, 1995, p. 1)

\section{IS THERE REALLY A NEED FOR A CHANGE?}

The June 2018 issue of the member's journal of the British Psychological Society carried on its cover a drawing of a very large seated elephant with a circus type of mantle on its back inscribed with the word 'policy'. In a Lilliputian reference, it was being held up by a host of tiny figures and the cover bore the words 'Can psychologists shift public policy?'. The article to which the cover referred was a critique of the way psychologists produce an imaginary rational version of policy, policy makers and the policy process, along with an equally rational view of their (the psychologists') capacity to influence affairs; instead of recognizing that what exists 'is a dauntingly complex and ideologically riven mess of relations, where the evidence of psychologists exists as one, not especially compelling, presence in a range of actors, agents, networks and pressure groups' (Walker et al., 2018, p. 40). What perhaps is more important for Beyond Public Policy is the size of the elephant in relationship to the psychologists; the fact that it was an elephant that was chosen to represent policy; and the one little figure who stands in front of 
the elephant, raising her arms as if to say, 'Listen to me'. Has policy outgrown its conceptual space and contribution? Has it stopped being useful and become something very different? Does it need to shrink back to normal size? Similar arguments have been made by Orren and Skowronek (2017) about the way in which policy has taken over the public sphere in the USA, creating what they have called 'The Policy State':

... policy has expanded its role in American government and society by eroding the boundaries and dissolving the distinctions that once constrained policy's reach. As we show, greater reliance on policy has the consequence of rendering all aspects of state authority more homogeneous and making each more difficult to pin down. A protracted history of collective problem solving has in this way created a set of problems for American government that more policy is unlikely to remedy.

Our proposition is that policy has not filled a void in governance; rather, it has dislodged governance previously in place. Examining the matter that way points to the impact of policy's expansion on the fundament of rights and on formal structures of decision making. Rights and structure, we contend, grow more attenuated and uncertain as policy proliferates and assumes dominance. When we call this troubled accretion a "policy state", we are referring to the effects on elements and modes of government that in earlier times bore little resemblance to policy, indeed represented an opposite set of governing principles. (Orren and Skowronek, 2017, p. 6)

Over the last 60 years, edging its way to the centre of a stage already fairly full of different ways of talking about and doing public affairs, policy gradually came to assume the role of the official articulator of public life in western democracies and to represent the broad idea of government in action. Evidence that 'policy' is serious and important comes from the many courses, journals, conferences, policy professionals and advisors, as well as different theories about policy processes and about how policy happens. Very present in these different arenas is the view of policy as the result of authoritative figures, in the institutional and hierarchical sense, making technically informed choices from which practices are introduced, implemented and evaluated. Colebatch and colleagues critically refer to this as the narrative of authoritative instrumentalism and in a number of texts have shown that this official account bears very little resemblance to policy work itself, when seen in the day to day of those who are practically involved (Colebatch, 2006, 2010; Colebatch et al., 2010). There are conflicting views and versions around and, as they argue, somehow it is necessary to work with them. This is a position also shared in part by those involved in various approaches to critical, deliberative or interpretative policy analysis (Fischer, 2003; Hajer 
and Wagenaar, 2003) and also in earlier texts on argumentation and policy (Majone, 1989). However, even here and despite the broadening out of analysis and the questions posed, the language of policy remains active, suggesting that it serves some purpose or purposes.

The variety of definitions and approaches that Theodoulou mentions was, it appears, an early feature of the policy arena. In 1978, Edwards and Sharkansky were to say:

There is no single definition of public policy. It is what governments say and do, or do not do. It is the goals or purposes of government programs, for example the elimination of ignorance and poverty. Policy is also the important ingredient of programs, like the requirement that all elementary school teachers be college graduates, or the compulsory division of funds earmarked for education between vocational and liberal arts programs. Policy further includes the implementation of intentions and rules.

Policy may either be stated explicitly - in laws or in the speeches of leading officials, or implied in programs and actions. Implicit policy may be apparent only to those who are intimately familiar with the details of programs and able to discern patterns in the sum total of what is being done. Indeed, some policies consist in a lack of action and may be especially hard to discern if officials wish to conceal their real purpose; the decision by local authorities to evade a high court mandating racial integration constitutes such a policy-through-inaction. A change in policy may be proposed or debated in public with the full participation of interest groups and the mass media, or policy may change covertly, as when a chief executive decides to embark on a new venture under a cloak of secrecy or with a contrived explanation designed to mislead the public. (p. 2)

A critic might ask, what is the public policy they are talking about? And an answer might be that very similar difficulties to define what 'it' is, are common in all social ideas. The joint production of meaning both as description and action can make the answer 'you know it when you see it' not as illogical as it may seem. Others might suggest that public policy is no longer able to give an adequate account of public affairs and that there are other contenders for the centre stage, newer kids on the block, edging their way forward. Governance is already being pushed forward as a better replacement for the articulating role, with very much the same type of argument as has been used from time to time with public policy. The discussion of self-organizing, inter-organizational networks within a governance framework, ${ }^{14}$ for example, may leave little space for authoritative instrumentalism of the orthodox kind but also raises many questions around modes of rationality ${ }^{15}$ and governmentality, ${ }^{16}$ which suggests that much more is involved than a simple broadening out of perspectives and actors. 
While talk and exchange of arguments are a key part of it, the whirl of organisational routines, practical judgements, subjective voices, personal histories and improvisational practices are equally important. For the countless administrators, elected officials, street-level bureaucrats, professionals, activists and ordinary citizens who are involved in struggling with collective problems, governance is above all about 'intervening' in practice. We have barely begun to fathom what an interventionist approach to politics, governance and public policy might look like. (Griggs et al., 2014, location 365, Kindle edition)

The Public Policy and Administration Research Committee of the International Political Science Association (IPSA) in its session information for the 2018 IPSA Conference, seems to be recognizing that agendas are moving, by commenting that while the early focus of the committee was on 'policy analysis, over time this has broadened to take in the full range of practices aimed at "steering" public activity' (RC 32, 2018). Steering and governance, it should be noted, share the same roots, and the image of 'steering' and 'rowing' has been much evoked in the discussion of public management - both positively and negatively.

Beyond Public Policy shares these doubts but moves the focus away from the discussion about new paradigms and successors. There is no doubt that policy has made an important contribution, but what about all the other social languages for enacting governing and collective life, some of which as mentioned were involved in talking into place the different versions of the western welfare state $^{17}$ well before what has been called public policy's high modern period. ${ }^{18}$ What happened to those other performative languages, those ways of doing things with words?

Here it is important to acknowledge an earlier analysis of some of these issues by Hale (1988), who pointed out how textbooks in public administration in the early 1980s moved effortlessly towards policy. As he put it: "The old paradigm is dead; the new paradigm is the "administrative policy making paradigm" in which administrators are not simply "enmeshed" or "involved" in politics - but have become full-fledged policymakers' (p. 428). In a similar manner to public administration, political science texts on American politics and government became texts on policy making in America and, in doing so, focused on the short-term process of the policy itself rather than the institutional, social and organizational history of the issues and actors involved. As Hale remarks: 'politics has been replaced by process: nobody ever does anything; things just happen.' (p.442). Closing the circle, he argued, administration moves away from the execution of laws and bills to a new sphere of action 'implementation', that is activities directed to putting a programme into effect. 
Which way forward? The answer, as the evidence suggests and the book proposes, lies in adopting a broader and somewhat chaotic approach to public affairs, based on a diversity of social languages that may cooperate, enter into conflict or act independently of one another, taking seriously Rosanvallon's proposal of a contentious process. Young (2000) introduced the idea of a decentred and 'agonistic' approach to deliberative democracy, in which: 'Disorderly, disruptive, annoying or distracting means of communication are often necessary or effective elements in such efforts to engage others in debate over issues and outcomes' (p. 50). This suggests the importance of considering, with equal intensity, not only the different ways of performing those actions that are normally associated with government but also those that come from the public(s) themselves. This orientation provides the structure for the book.

\section{STRUCTURE}

Beyond Public Policy is not about a simple addendum to government in action which might be referred to in some contextual way as civil society, the civic arena or just society. On the contrary, it argues that there are at least as many different social action languages present when people(s) act to pressure government or when they get on with solving problems themselves, as there are to be found in the offices of ministries, departments and public service agencies. That is, that there is no single social language for government in action nor for society in action; there are just lots of heterogeneous social languages, lots of bits and pieces of soft and hard technologies. Some of these are newer versions of previous notions of practice, others may be hybrid mixtures and others still will be edging their way forward. Some see themselves as central to public affairs, others are just about getting on with making things happen. They move in and out of each other, sometimes in conflict, sometimes in cooperation, or, often, just going their own way. The structure of the book reflects this position.

There are two chapters that look at public action languages from within the arena of governing and two chapters that look from within various forms of social and community-based action. None is completely separate and they draw on different historical moments, including the present, to provide examples of emerging social languages and the way that certain themes were discussed. These four more empirical chapters are complemented by a chapter on the idea of social languages from a theoretical standpoint and a final chapter that draws some of the threads 
together and takes a somewhat critical look at the limits of the negotiation of possibilities. Chapter 1 has introduced the general argument and provided some glimpses of themes that will be returned to in subsequent chapters. The choice of a structure which moves backwards and forwards between different themes and examples reflects a conscious attempt to show a little of the amazingly curious way in which ideas move around and to make more visible the density of the public action scene.

Chapter 2 begins with a discussion of public(s) and the way that public issues and problems are formed. The focus, however, is not on how governments deal with these, but how people themselves got on with and continue to get on with solving what they saw as problematic. Resistance is one of these, shown in examples of reaction to slavery in Brazil and the USA; alternatives are others, as in the Jesuit missions in Latin America. Resistance and alternatives come together in the Paris Commune and in the early days of the Rochdale cooperative store. A second line of analysis looks at civil society, philanthropy and parishes, focusing on some of the different social languages that emerge when people take care of each other in the everyday. This will lead, in turn, to another broad area of public action: the creation of new kinds of institutions such as orphanages and international associations which in different ways laid the basis for current discussions of public concerns.

Chapter 3 starts with some examples of words in action and social organization during the late medieval and Renaissance periods: the Crusades, the Hanseatic League and the Treaty of Westphalia. The three set the tone for the theoretical part of the chapter for they show the intersection of expressions and actions, point to social and administrative skills and illustrate the role that language(s) played in forming and shaping one of the early 'professions' on the public affairs scene, that of diplomacy. The chapter goes on through a brief mention of the history of ideas and language to focus on the main theoretical theme that is present in the book, that of the performative approach to language as social action and social languages themselves as forming a very heterogeneous landscape of ways of doing things with words. It finishes with another, this time recent, public sector profession that, like diplomacy, has words at the centre of its attention in a very particular way: the speechwriter.

Chapter 4 concentrates on three periods of intense governmental activity which, in their different ways, were crucial in crafting some of the bits and pieces of democratic welfare states and influencing others. Milestone changes were introduced and urgent social and development issues were tackled, without much of a policy in sight. In the first two, where there is much material already published, the focus will be on specific themes: the Roosevelt period and specifically the Tennessee 
Valley Authority and public planning; the 1945 Labour Government led by Attlee in the UK with a comment on the Beveridge Report, seen as key for social policy, and the introduction of the National Health Service. On the third, the domestic part of the Johnson Administration in the USA, the interest is broader, for it is often cited as the period when public policy came of age but where a closer look at internal documents suggests a different conclusion. The chapter finishes with the UK's Fulton Report which marked the 'formal' introduction of a new version of policy within the civil service and the arrival of the policy advisor.

Chapter 5 starts with an overview of the way that policy would continue to spread out both in terms of use by governments and scholars in discussing public affairs and in its application to new themes, such as implementation. It then goes on to look at a number of different places and areas in which policy might be found along with other action languages, such as the EU and the Treaty of Rome, the United Nations Educational Scientific and Cultural Organization's (UNESCO's) work on cultural policy in the 1960s and 1970s, as well as the government reform movements in the following periods, especially in the countries of the Organisation for Economic Co-operation and Development (OECD). It then traces through the various reform movements in Latin America which demonstrate the dedication to public management and administrative improvement but also raise questions about the relative delay in adopting public policy as a way of looking at public affairs. Here the case chosen is that of Brazil where studies of bibliographies, newspapers and academic publications are complemented by a case study in the area of HIV/AIDS.

Rights as an action language have been very present in the developing world as a mobilizing agenda and, as elsewhere, were present well before policy reached the centre stage. Now, in both the developed world and developing worlds, they are serving to challenge policy and suggest other forms of taking the democratic experience forward. Chapter 6 takes this as a starting point to return to some of the events and debates around the introduction of rights within the United Nations, especially around the very idea of rights itself. From this it picks up the theme of the intersection of social languages with a reworking of the idea of civic engagement in different ways, including the languages of civil disobedience. It goes on to look at the languages of mobilization and community organization as well as those of social movements, crowds and protests. It closes by looking at ways in which some of these social languages are also joining with public sector social languages in creating new mechanisms of decision - for example in the area of participative budgeting 
and what have been called hybrid arenas, as well as civic-based cooperation in service provision.

In Chapter 7, these different themes and examples from different sides of the public affairs arena are brought together in response to the three points raised in the introduction: the heterogeneity of social languages in the public affairs arena; the problems with centrality; and the fact that there are just as many social languages for being and doing 'public' outside the generally assumed circles of governing as there are inside. It begins with an example of a setting in which there is very little contact between these different social languages and shows how this can have a major impact on a recurrent theme in the public affairs arena in both the developed and developing world - social, material and institutional vulnerability. It then goes on to look at whether public policy will survive and in what form, and what the promises are for governance, in part through the way the expressions are being incorporated in different national and international arenas. It concludes by arguing that the public action languages approach - as an approach and not a theory - offers a stimulus to look for and recognize the multiplicity of the many different social languages present and a more promising basis on which to take on the challenge of building links between repertories and of negotiating possibilities.

\section{A BRIEF NOTE ON METHODS}

The author is a social and organizational psychologist who has had the opportunity of working in interdisciplinary settings for most of his research life, during which time he has been involved in applied social research in various areas of public administration and government in the developed and developing world. Like most applied researchers, he has learned to have a high respect for the work of others in their specialist disciplinary fields, while also recognizing that despite epistemological differences, methods have more to do with 'how it's done' than 'how it should be done'.

To begin with it is necessary to emphasize that this is not a history of ideas but, as can be seen from this introduction, going beyond policy requires moving outside policy and this implies looking before, during and, even, after. Inevitably, there are many ideas in circulation and while there is no intention of redoing the work of historians, their contributions have been important, as have many of those in the different applied social sciences who have described the emergence of their own professions or questioned the centrality of certain approaches from different disciplinary 
standpoints. From discourse analysis - as well as learning how to seek out the nuances in texts and the importance of public domain documents as themselves products of talk in action - has come the practice of avoiding short citations. Single words are never uttered as single words; as talk flows it forms chunks of meanings in the same way that written texts form sentences and paragraphs. Archival material, public domain documents, case studies and many conversations are also part of the book. The choices made about which events to make more visible are both academic and also literary, for this is also a collection of stories about some of the ideas and the languages that perform public affairs, and curiosity always has a part to play. Without doubt, readers will be able to point to other examples and key moments when other ideas for public action emerged and, if this happens, the purpose of the book has been fulfilled.

In many cases, it has been possible to go back to original texts in administration and policy, official documents, or cross-check with different accounts of what was discussed. Biographies of some key figures have also proved very helpful as well as a number of historical analyses of earlier and relatively current events. The main empirical focus has been towards the USA, the UK and Latin America. In the case of the first two, this is because there seems to be agreement in the field that they played a key role in the emergence of the public policy narrative. Latin America has been a very interesting site from which to follow the gradual spread of administrative terms and practices, including the arrival of policy; helped also by some familiarity with language. Theoretically the reach has been wider within the European democracies and especially, in relation to the public action languages approach, France. However, this is simply a reference to the physical and linguistic location of scholars and not a suggestion of a school of thought. There is no more a French approach to public action as there is a USA approach to public policy.

Many other versions of each of the chapters could be written and there are many more stories to be told; especially by scholars coming from other linguistic backgrounds who can follow the way in which terms are taken from one language to another in other linguistic spaces and places. Indeed, there is much work to be done.

\section{NOTES}

1. Young (1979), also Cox (1905).

2. Finer (1997).

3. For example, Skinner's Liberty Before Liberalism (1998).

4. Burke (1992) and Ashford (1991). 
5. Gilbert and Mulkay (1984), see also M.J.P. Spink (1999) for a discussion in the area of health.

6. Fischer et al. (2015).

7. Fuller (1988).

8. Friedmann (2011).

9. See the academic dictionary article by Commaille (2014).

10. Translations from the French, Portuguese and Spanish citations have been made by the author and colleagues.

11. Alexander (1981) suggested that the lack of impact of Wildavsky's (1973) 'If Planning is Everything, Maybe it's Nothing' amongst planners may have been due to its being published in a journal (Policy Sciences) that planners didn't read.

12. Blake (1996).

13. The Shorter Oxford English Dictionary on Historical Principles, Vols I and II (1973).

14. Rhodes (1996).

15. Hoppe (2002).

16. Burchell et al. (1991) and Enroth (2013).

17. Garland (2016).

18. Goodin et al. (2006). 